\title{
FIRST RECORD OF NEOSCOPELUS MACROLEPIDOTUS JOHNSON, 1863 (ACTINOPTERYGII: MYCTOPHIFORMES: NEOSCOPELIDAE) FROM IRISH WATERS (PORCUPINE BANK, NORTH-EASTERN ATLANTIC)
}

\author{
Francesc ORDINES ${ }^{1 *}$, Ronald FRICKE ${ }^{2}$, Florencio GONZÁLEZ ${ }^{3}$, and Francisco BALDÓ ${ }^{4}$ \\ ${ }^{1}$ Instituto Español de Oceanografía - Centre Oceanogràfic de les Balears, Palma, Spain \\ ${ }_{2}^{2}$ Im Ramstal 76, 97922 Lauda-Königshofen, Germany \\ ${ }^{3}$ Instituto Español de Oceanografia - Centro Oceanográfico de Gijón/Xixón, Gijón/Xixón, Spain \\ ${ }^{4}$ Instituto Español de Oceanografía - Centro Oceanográfico de Cádiz, Cádiz, Spain
}

\begin{abstract}
Ordines F., Fricke R., González F., Baldó F. 2017. First record of Neoscopelus macrolepidotus Johnson, 1863 (Actinopterygii: Myctophiformes: Neoscopelidae) from Irish waters (Porcupine Bank, northeastern Atlantic). Acta Ichthyol. Piscat. 47 (1): 85-89.
\end{abstract}

\begin{abstract}
The blackchin, Neoscopelus macrolepidotus Johnson, 1863 (known also as large-scaled lanternfish), originally discovered at Madeira, is a globally distributed benthopelagic fish species that inhabits depths between 300 and $1100 \mathrm{~m}$ in the tropical and subtropical regions. Despite the sampling site of the original description, the species seems to be very rare in the eastern Atlantic, particularly at northern latitudes. The worldwide distribution of the species seems to be restricted to latitudes lower than $45^{\circ}$ either in the Southern and Northern Hemisphere. During the Porcupine 2016 bottom trawl survey a specimen of $N$. macrolepidotus was collected at a depth of $628 \mathrm{~m}$ and latitude $51^{\circ} \mathrm{N}$ in the Porcupine Bank, situated in the north-eastern Atlantic, approximately $204 \mathrm{~km}$ off the west coast of Ireland. This is the first record of the species in the Porcupine Bank. It significantly extends the distribution range of $N$. macrolepidotus and represents the highest latitude reported for this species either in the Northern or Southern Hemisphere. This extended distribution may have been facilitated by the course of the Mediterranean Outflow Water, which on its way to the north-eastern Atlantic reaches the slope of the Bank at depths where N. macrolepidotus is usually distributed.
\end{abstract}

Keywords: blackchin fish, highest latitude record, extended distribution, Mediterranean Outflow Water

\section{INTRODUCTION}

The genus Neoscopelus was established to accommodate the species Neoscopelus macrolepidotus Johnson, 1863, discovered at Madeira (Johnson 1863). The latter fish, known under alternative common names of blackchin or large-scaled lanternfish, is a globally distributed benthopelagic species that inhabits depths between 300 and $1100 \mathrm{~m}$ in tropical and subtropical regions (Nafpaktitis 1977, Hulley 1986, 1990, Burgess and Branstetter 1985, Lloris 1986, Roberts 2015). Along with Neoscopelus microchir Matsubara, 1943, with which shares similar morphological traits, these are the only two species of Neoscopelus reported from the Atlantic Ocean. The third species described within this genus, Neoscopelus porosus Arai, 1969, is only distributed in the Indo-Pacific region.

In the Atlantic, the majority of the records of N. macrolepidotus come from the tropical and subtropical western Atlantic. Neoscopelus macrolepidotus was recorded from off Dominica, off Martinique, and the northern Gulf of Mexico by Goode and Bean (1896), from off southern Brazil and off northern Argentina south to $38^{\circ} 38^{\prime} \mathrm{S}$ by Nafpaktitis (1977) and from various locations in the Gulf of Mexico, Caribbean Sea, and off northern Brazil by Burgess and Branstetter (1985). Recently, the distribution range in the north-western Atlantic was extended northwards by Moore et al. (2003), with a new record at $40^{\circ} 45^{\prime} \mathrm{N}$ off Cape Hatteras (North Carolina, USA).

In the eastern Atlantic, Neoscopelus species seem to be very rare. In the north-eastern Atlantic, further than the first record of the genus Neoscopelus (i.e., the specimen from Madeira used in the original description of $N$. macrolepidotus), there have only been few other records from the following areas:

- Morocco (Vaillant 1888);

- Madeira (Maul 1951);

- Western Sahara (Maurin et al. 1977);

- Namibia (Lloris 1986); 
- The south-eastern central Atlantic at $38^{\circ}-39^{\circ} \mathrm{S}$ (Bekker and Shcherbachev 1990).

The Galician coast and the Galician Bank (a large seamount located at $230 \mathrm{~km}$ off the Galician coast), both areas at $42^{\circ}-43^{\circ} \mathrm{N}$ (Bañón et al. 1997, 2016). The latter are the northernmost records of the species in the Atlantic (Fig. 1).

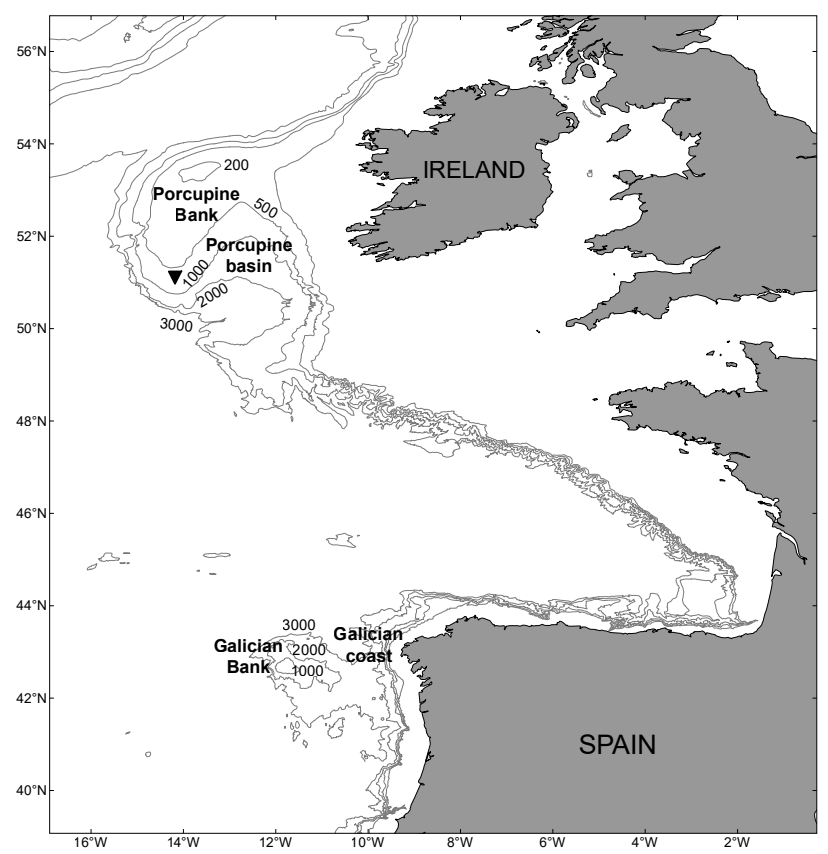

Fig. 1. Map showing the location of the bottom trawl sampling station where the specimen of Neoscopelus macrolepidotus was collected in the Porcupine Bank $(\boldsymbol{\nabla})$; It also shows the areas off Galicia where the previous northernmost records for the species in the Atlantic had been reported; The isobaths corresponding to $200,500,1000,2000$, and $3000 \mathrm{~m}$ are also shown

Otherwise, the Neoscopelus species are known to occur north to $40^{\circ} 45^{\prime} \mathrm{N}$ in the north-western Atlantic (Moore et al. 2003), south to $38^{\circ} 38^{\prime} \mathrm{S}$ in the southwestern Atlantic (Nafpaktitis 1977), south to ca. $40^{\circ} \mathrm{S}$ in the south-eastern Atlantic and Indian Ocean (Bekker and Shcherbachev 1990), north to ca. $30^{\circ} \mathrm{N}$ in the northwestern Pacific (various authors), and south to $44^{\circ} \mathrm{S}$ at Chatham Islands (New Zealand), in the south-western Pacific (Roberts 2015). So far, the New Zealand findings represent the highest latitude records of the genus Neoscopelus and of the species $N$. macrolepidotus in the Southern Hemisphere.

The present work reports the first, and the highest latitude, record of the genus Neoscopelus and the species N. macrolepidotus from the Porcupine Bank (off the west coast of Ireland).

The specimen studied was collected during the bottom trawl survey PORCUPINE 2016. The survey was carried out on board of the R/V Vizconde de Eza at the Porcupine Bank. The fishing gear used during the survey was the otter bottom trawl Porcupine Baca 40/52 (Anonymous 2010) with a codend mesh size of $20 \mathrm{~mm}$. The specimen was preserved in $70 \%$ ethanol and is now deposited in the collection of the Instituto Español de Oceanografía in the Centro Oceanográfico de Santander with the reference number IEO-ST-PC16/056.

The Porcupine Bank is situated in the north-eastern Atlantic, approximately $204 \mathrm{~km}$ off the west coast of Ireland (Fig. 1), within the Irish EEZ. The shallowest depth on top of the Bank is at $150 \mathrm{~m}$. It is limited at its western part by a steep drop-off that descends abruptly from around 450 to more than $3000 \mathrm{~m}$. The eastern part is connected to the Irish shelf by the narrow Slyne Ridge, with a depth of around $330 \mathrm{~m}$. In the north the slope is also steep and limited by the Rockall Trough with depths between 2000 and $3000 \mathrm{~m}$, whereas the slope in the southern part is not so steep, forming in the south-eastern region, between the Bank and the Irish shelf, the Porcupine Seabight (Velasco et al. 2008).

The individual (143 mm standard length) was caught at a depth of $628 \mathrm{~m}$, at $51^{\circ} 06.07^{\prime} \mathrm{N}$ and $014^{\circ} 10.98^{\prime} \mathrm{W}$ (Fig. 1). The net and the abundant catch in that sample $[383 \mathrm{~kg}$ in total, including $136 \mathrm{~kg}$ of Argentina silus (Ascanius, 1775), $49 \mathrm{~kg}$ of Micromesistius poutassou (Risso, 1827), $29 \mathrm{~kg}$ of Lepidion lepidion (Risso, 1810), $25 \mathrm{~kg}$ of Phycis blennoides (Brünnich, 1768), and $24 \mathrm{~kg}$ of Galeus melastomus Rafinesque, 1810]. Although the studied specimen was slightly damaged (Fig. 2), the meristic and morphometric traits required for its identification could be obtained (Table 1). Most fins were damaged, including the caudal, which prevented us from measuring the total length. The ventral part was damaged. Even though, gonads were not lost, allowing us to determine that the specimen was a female. The presence of the adipose fin is typical for species of the family Neoscopelidae, and the photophores characterise it as a species of the genus Neoscopelus. The species was identified as $N$. macrolepidotus due to the presence of a single lateral luminous organ series (LO) (4 in $N$. porosus) consisting of 12 photophores that ended before the anal fin (20-22 photophores ending near the posterior end of the anal fin in $N$. microchir) (Fig. 2), and $2+1+8$ (total 11$)$ gill rakers $(3+1+10$, total 14 in N. microchir). Other morphometric and meristic traits are summarized in Table 1.

The presently reported record significantly extends the distribution range of the genus Neoscopelus and the species $N$. macrolepidotus further north. At $51^{\circ} \mathrm{N}$ it represents the highest latitude reported for this species either in the Northern or Southern Hemisphere. Moreover, this record is added to the recently reported ones of Gadella maraldi (Risso, 1810) and Bellottia apoda Giglioli, 1883 from the slope of the Porcupine Bank. Those cases also represented a significant northward extension of the previous distribution of both species, whose northernmost distribution was considered the waters off the Iberian Peninsula at $43^{\circ}$ and $37^{\circ} \mathrm{N}$ for G. maraldi and B. apoda, respectively (Ruiz-Pico et al. 2012, Fernández-Zapico et al. 2013).

Although the Porcupine Bank is situated at a latitude of more than $50^{\circ} \mathrm{N}$, its slope is influenced by the relatively warm and saline Mediterranean Outflow Water (MOW), a 
Table 1 MOW flows northward as a mid-depth boundary current

Morphometric and meristic characteristics of the specimen of Neoscopelus macrolepidotus (IEO-STPC16/056) from the Porcupine Bank

\begin{tabular}{lc}
\hline \multicolumn{1}{c}{ Morphometric and meristic characters } & Value \\
\hline SL & 143.5 \\
Head length & 45.5 \\
Preorbital length & 9.6 \\
Eye diameter & 9.9 \\
Interorbital length & 8.3 \\
Predorsal length & 61.5 \\
Dorsal-fin base length & 9.0 \\
Anal-fin base length & 6.9 \\
Preanal length & 103.8 \\
Origin adipose fin to caudal peduncle & 25.6 \\
Upper maxilla length & 24.2 \\
Body width & 15.4 \\
Depth at anal fin origin & 25.9 \\
Weight & 42.0 \\
Dorsal-fin rays & 12 \\
Anal-fin rays & 11 \\
Pectoral-fin rays & 18 \\
Pelvic-fin rays & 8 \\
Gill rakers & $1+8(11)$ \\
LO & 12 \\
\hline
\end{tabular}

Lengths are in $\mathrm{mm}$; weight in g; LO: number of photophores in the lateral luminous organs series.

water mass originating in the deep Mediterranean Sea that outflows into the north-eastern Atlantic Ocean through the Strait of Gibraltar. Despite the flux of MOW through the Strait of Gibraltar is relatively small, on the order of $10^{6} \mathrm{~m}^{3} \cdot \mathrm{s}^{-1}$, the northward penetration of this water mass is of great interest due to it is involved in the water mass distribution of the North Atlantic, and because it is believed to be a source of heat and salt for the Nordic seas, which involves a potential role in the World Ocean circulation (Jia et al. 2007, Lozier and Steward 2008). The along the west coast of the Iberian Peninsula, reaching Bay of Biscay, and onward toward Porcupine Bank (Lozier and Steward 2008). This water mass exits the Strait of Gibraltar with a salinity of $38.4 \%{ }^{*}$, which decreases in its way northwards to a mean salinity of $35.65 \%$ in the Bay of Biscay (Iorga and Lozier 1999), still higher than the salinity of the other two main sources of water in the North Atlantic basin, the sub-polar water $(<35 \%)$ and the subtropical water $(>35 \%$ ond $<35.6 \%$ ) (Chaudhuri et al. 2011). The influence of the MOW in the north-eastern Atlantic has been related to climatic variability, with MOW reaching higher latitude in years with negative values of the North Atlantic Oscillation (NAO). In such cases, MOW could penetrate past Porcupine Bank into the sub-polar gyre (Lozier and Steward 2008, Chaudhuri et al. 2011).

The catch of the specimen reported here could have been originated by the migration of individuals from the closest reported north-eastern Atlantic populations, those in the Galician Bank and the continental slope of the Galician coast (Bañón et al. 1997, 2016). This migration could have been facilitated by following the relatively warmer MOW on its way to the north-eastern Atlantic during a period of low NAO and higher influence of MOW on the Porcupine bank. In these periods, the MOW is present on the slope of the Porcupine Bank in depths between 400 and more than $2000 \mathrm{~m}$ (Chaudhuri et al. 2011), a bathymetric range that includes those depths where $N$. macrolepidotus is usually found.

The MOW contribution to the northward distribution of species from lower latitudes has already been suggested before by De Mol et al. $(2002,2005)$ who hypothesized that the large deep-water coral banks of Lophelia and Madrepora in the Porcupine basin could have been originated by the introduction of larvae transported by the MOW from the Mediterranean to the northeast Atlantic. The same pathway of dissemination has also been suggested for the Polynoidae polychaetes, Harmothoe

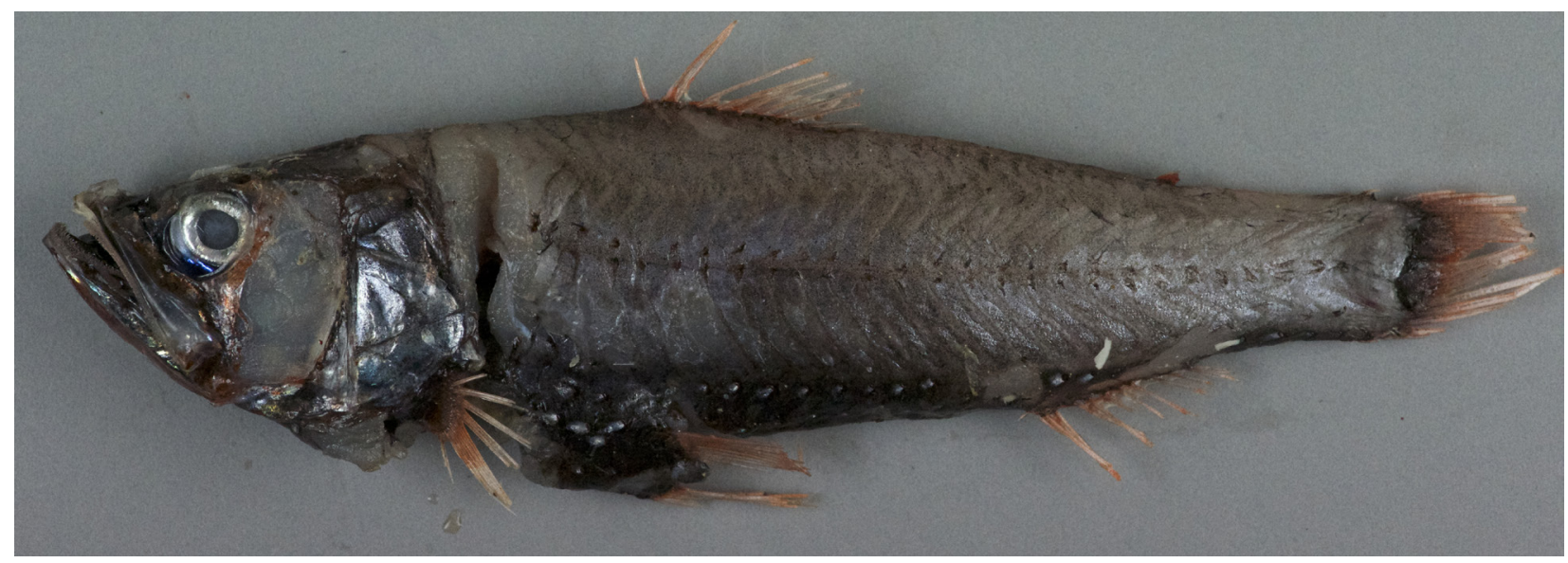

Fig. 2. Specimen of Neoscopelus macrolepidotus from the Porcupine Bank (IEO-ST-PC16/056)

"In the wake of the growing criticism of the Practical Salinity Scale concept (and especially PSU as a "unit"), Acta Ichthyologica et Piscatoria is in favour of expressing salinity in parts per thousand (\%), regardless if a direct or indirect method was employed to determine the water salinity. 
vesiculosa and Neolagisca jeffreysi which live associated to deep-water coral banks and have only been found in the western Mediterranean and scattered places in the north-eastern Atlantic including the southwest of Ireland (Fiege and Barnich 2009). Along with the recent new records of B. apoda and G. maraldi in the Porcupine bank, the presently reported record of $N$. macrolepidotus adds evidences for the possible role of MOW in the northward dissemination of fish species from lower latitudes.

\section{ACKOWLEDGEMENTS}

The authors wish to thank all participants in the PORCUPINE 2016 research cruise and the crew of the $\mathrm{R} / \mathrm{V}$ Vizconde de Eza for their help during the sampling. The cruise was supported by the Instituto Español de Oceanografía and by the Data Collection Framework for the EU Common Fisheries Policy.

\section{REFERENCES}

Anonymous 2010. Manual for the international bottom trawl surveys in the western and southern areas. Revision III, 22-26 March 2010, Lisbon, Portugal. ICES CM 2010/SSGESST:06. Addendum 2.

Bañón R., Arronte J.C., Rodriguez-Cabello C., Piñeiro C.-G., Punzon A., Serrano A. 2016. Commented checklist of marine fishes from the Galicia Bank seamount (NW Spain). Zootaxa 4067 (3): 293-333. DOI: 10.11646/zootaxa.4067.3.2

Bañón Díaz R., Casas Sánchez J.M., Piñeiro Álvarez C.G., Covelo M. 1997. Capturas de peces de afinidades tropicales en aguas atlánticas de Galicia (noroeste de la península Ibérica). Boletín del Instituto Español de Oceanografía 13 (1-2): 57-66.

Bekker V.E., Shcherbachev Yu.N. 1990. Benthypelagic species of the families Neoscopelidae and Myctophidae from the Indian Ocean, with a description of a new species of Diaphus. Journal of Ichthyology 30 (7): 122-134.

Burgess G.H., Branstetter S. 1985. Status of Neoscopelus (Neoscopelidae) in the Gulf of Mexico with distributional notes on Caulolatilus chrysops (Branchiostegidae) and Etelis oculatus (Lutjanidae). Northeast Gulf Science 7 (2): 157-162.

Chaudhuri A.H., Gangopadhyay A., Bisagni J. 2011. Contrasting response of the eastern and western North Atlantic circulation to an episodic climate event. Journal of Physical Oceanography 41 (9): 1630-1638. DOI: 10.1175/2011JPO4512.1

De Mol B., Henriet J.-P., Canals M. 2005. Development of coral banks in Porcupine Seabight: Do they have Mediterranean ancestors? Pp. 515-533.

DOI: 10.1007/3-540-27673-4 26. In: Freiwald A., Roberts J.M. (eds.) Cold-water corals and ecosystems. Springer Verlag, Berlin.

DOI: $10.1007 / 3-540-27673-4$

De Mol B., Van Rensbergen P., Pillen S., Van Herreweghe K., Van Rooij D., McDonnell A., Huvenne V., Ivanov M., Swennen R., Henriet J.P. 2002. Large deep- water coral banks in the Porcupine Basin, southwest of Ireland. Marine Geology 188 (1-2): 193-231.

DOI: 10.1016/S0025-3227(02)00281-5

Fernández-Zapico O., Arronte J.C., Ruiz-Pico S., Velasco F., Baldó F. 2013. First record of Bellottia apoda (Ophidiiformes, Bythitidae) from Irish Waters (north-eastern Atlantic). Journal of Ichthyology 53 (2): 195-198.

DOI: $10.1134 / \mathrm{S} 0032945213020124$

Fiege D., Barnich R. 2009. Polynoidae (Annelida: Polychaeta) associated with cold-water coral reefs of the northeast Atlantic and the Mediterranean Sea. Zoosymposia 2: 149-164.

DOI: $10.11646 /$ zoosymposia.2.1.13

Goode G.B., Bean T.H. 1896. Oceanic ichthyology, a treatise on the deep-sea and pelagic fishes of the world, based chiefly upon the collections made by the steamers "Blake," "Albatross," and "Fishhawk" in the northwestern Atlantic, with an atlas containing 417 figures. Memoirs of the Museum of Comparative Zoölogy at Harvard College Vol. 22. [In two parts.]

Hulley P.A. 1986. Family No. 87: Neoscopelidae. Pp. 321322. In: Smith M.M., Heemstra P.C. (eds.): Smiths' Sea Fishes. Macmillan South Africa, Johannesburg.

Hulley P.A. 1990. Neoscopelidae. Pp. 468-469. In: Quéro J.C., Hureau J.C., Karrer C., Post A., Saldanha L. (eds.) Check-list of the fishes of the eastern tropical Atlantic. Volume 1. CLOFETA. UNESCO, Paris.

Iorga M.C., Lozier M.S. 1999. Signatures of the Mediterranean outflow from a North Atlantic climatology: 1. Salinity and density fields. Journal of Geophysical Research 104 (C11): 25985-26009. DOI: 10.1029/1999JC900115

Jia Y., Coward A.C., de Cuevas B.A., Webb D.J., Drijfhout S.S. 2007. A model analysis of the behavior of the Mediterranean water in the North Atlantic. Journal of Physical Oceanography 37 (3): 764-786. DOI: $10.1175 / J P O 3020.1$

Johnson J.Y. 1863. Description of five new species of fishes obtained at Madeira. Proceedings of the Zoological Society of London 1863 (1): 36-46.

Lloris D. 1986. Ictiofauna demersal e aspectos biogéograficos de la costa sudoccidental de África (SWA/Namibia). Pp. 9.432. In: Rucabado J.A. (ed.) Monografías de Zoología marina. Volumen 1. Barcelona.

Lozier M.S., Stewart N.M. 2008. On the temporally varying northward penetration of Mediterranean overflow water and eastward penetration of Labrador sea water. Journal of Physical Oceanography 38 (9): 2097-2103.

DOI: $10.1175 / 2008 J P O 3908.1$

Maul G.E. 1951. Nota sobre as duas espécies do género Neoscopelus. Boletim do Museo Municipal do Funchal 5 (13): 56-63.

Maurin C., Bonnet M., Quéro J.C. 1977. Poissons des côtes nord-ouest africaines (campagnes de la “Thalassa" 1962, 1968, 1971, et 1973). Clupéiformes, 
scopéliformes et cétomimiformes. Revue des Travaux de l'Institut des Pêches Maritimes 41 (1): 5-92.

Moore J.A., Hartel K.E., Craddock J.E., Galbraith J.K. 2003. An annotated list of deepwater fishes from off the New England region, with new area records. Northeastern Naturalist 10 (2): 159-248.

DOI: $10.2307 / 3858285$

Nafpaktitis B.G. 1977. Family Neoscopelidae. Pp. 1-12. In: Gibbs R.H.jr., Berry F.H., Böhlke J.E., Cohen D.M., Collette B.B., Eschmeyer W.N., Mead G.W., Merriman D., Pietsch T.W., Parr A.E. (eds.) Fishes of the western North Atlantic, Part 7. Memoir Sears Foundation for Marine Research. Yale University, New Haven, CT, USA.

Roberts C.D. 2015. 88 Family Neoscopelidae. Pp. 610-612. In: Roberts C.D., Stewart A.L., Struthers C.D. (eds.) The fishes of New Zealand. Vol. 3. Systematic accounts. Te Papa Press, Wellington, New Zealand.
Ruiz-Pico S., Arronte J.C., Bañón R., FernándezZapico O. 2012. Northernmost records of Gadella maraldi (Actinopterygii: Gadiformes: Moridae) in the North-eastern Atlantic. Acta Ichthyologica et Piscatoria 42 (3): 263-267. DOI: $10.3750 / A I P 2011.42 .3 .12$

Vaillant L.L. 1888. Expéditions scientifiques du Travailleur et du Talisman pendant les années 1880, 1881, 1882, 1883. Poissons. G. Masson, Éditeur, Paris, France.

Velasco F., Landa J., Barrado J., Blanco M. 2008. Distribution, abundance, and growth of anglerfish (Lophius piscatorius) on the Porcupine Bank (west of Ireland). ICES Journal of Marine Science 65 (7): 1316-1325.

DOI: $10.1093 /$ icesjms/fsn130

Received: 16 December 2016

Accepted: 1 February 2017

Published electronically: 31 March 2017 